\title{
Papillary Ependymoma
}

National Cancer Institute

\section{Source}

National Cancer Institute. Papillary Ependymoma. NCI Thesaurus. Code C4319.

A rare variant of ependymoma characterized by well formed papillae. Tumor cell processes abutting capillaries are usually GFAP-positive. Differential diagnoses include choroid plexus papilloma, papillary mening ioma and metastatic papillary carcinoma. (Adapted from WHO) 